\title{
INDUSTRY PERSPECTIVE ON JOURNALISM EDUCATION CURRICULUM IN MALAYSIA
}

\author{
${ }^{1}$ Norhafezah Yusof, ${ }^{2}$ Awan Ismail, ${ }^{3}$ Rizalawati Ismail, \\ ${ }^{4}$ Norizah Aripin, ${ }^{5}$ Azahar Kassim \& ${ }^{6}$ Mohd Sobhi Ishak \\ ${ }^{1,2,4-6}$ School of Multimedia Technology \& Communication \\ Universiti Utara Malaysia, Malaysia \\ ${ }^{3}$ Kulliyah of Islamic Revealed Knowledge \& Human Sciences \\ International Islamic University, Malaysia
}

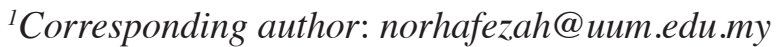

Received: 13 December 2017

Accepted: 1 May 2018

\begin{abstract}
Purpose - This study investigated media and communication practitioners' perspectives on the journalism education curriculum in Malaysia. Curriculum plays an important role in providing quality education for students. Journalism is a dynamic field that integrates industrial experience and fundamental knowledge in the field from higher educational institutions. Scholars in the field are divided on the issue of whether it is important for academia to consider input from industrial players in shaping the curriculum on journalism education in higher institutions of learning.

Methodology - Drawing from the researchers' experiences and guidelines from the Malaysian Qualifications Agency, the Taba Model was adapted as the theoretical framework for the study. The study used a semi-structured interview method. Fifteen experts were interviewed. They have served more than 10 years in the media industry and have held various executive positions. The interview protocol was developed based on the literature review and guidelines from the curriculum review of Communication and Media Studies. The interviews were conducted at the offices or homes of interviewees. Each interview ranged from 1 to 2 hours. The data was analysed using thematic analysis.
\end{abstract}

Findings - The findings revealed four main themes, namely 1) Strong general knowledge requirement, 2) the right skills matter, 3) 
Interest in the field - ability to adapt and learn, and 4) Specialised knowledge. The analysis of interviews indicated that curriculum needs to be revised based on academic convention and industrial needs.

Significance - These findings lend further support to the clarion call for industry and academia to collaborate extensively in nurturing high quality graduates in journalism.

Keywords: Communication and media, curriculum, industry, graduates, model.

\section{INTRODUCTION}

The curriculum plays an important role in providing quality education for students. This study focuses on the journalism education curriculum in institutions of higher learning from the perspective of the industry. Journalism is a dynamic field that integrates industrial experience and fundamental knowledge from higher educational institutions. The debate amongst scholars in the field is whether it is important for academia to consider input from industrial players when shaping the curriculum on journalism education in higher institutions of learning (Cullen, Tanner, O'Donnell \& Green, 2014, Gilmor, 2016). In the light of the current discourse on this issue, the present study is aimed at examining the industrial perspective on the curriculum of journalism education in Malaysia.

\section{Journalism Education: International Perspective}

A considerable amount of literature has been published on the perspectives of industry on journalism education. These studies have been conducted in Australia, the United States and United Kingdom, and Asia in general. In Australia, mainstream media employers have always placed a high premium on their employees having only traditional journalism skills (Callaghan \& McManus, 2010). Thus, graduates are not expected to master multimedia skills (Cullen et, al 2014). One study by Tanner, O' Donnell, Green and Cullen (2013) which examined graduate qualities and journalism curricula in Australia found that the university should play a key role in providing fundamental knowledge and skills training in 
journalism. There are disagreements on whether a university degree in journalism should be generalist, journalistic, theory-oriented or practical in nature. As a result, there is considerable diversity in the nature of programmes in the universities. In addition, the industry does not appear to have a role in shaping the curriculum. This state of affairs could lead to an unsatisfactory situation, whereby there is no alignment between industry needs and the prevalent academic curriculum. To compound matters, issues such as the constraints in financial and other resources are common, and educators are constantly challenged in their efforts to nurture quality student journalists (English, Fynes-Clinton \& Barnes, 2016).

On the other hand, journalism education in the United States is catching up with industrial demand (Anderson, 2017; Ryfe \& Messing, 2013). The specific term that is appropriate to describe journalism education in the United States is entrepreneurial journalism. It is an outcome of multiple crises in areas such as the economy, culture, technology, work-flow and politics (Anderson, 2017). Entrepreneurial journalism considers journalists as entrepreneurs who have independent and innovative values, whether they work with others or on their own (Anderson, 2017). Thus, to survive in an increasingly challenging sector, journalism educators are pursuing and developing entrepreneurial journalism to prepare journalists for future workplaces.

Journalism education in the United Kingdom is to a certain extent impacted by the tumultuous relationship between academia and industrial players (Temple, 2009). Temple argued that the university should not be left alone to do the job when training young journalists. Industry needs to complement the university in conducting the training, as at the end of the day the student journalists who have graduated will someday serve the industry. It has also been suggested that the theoretical framework that has been derived from Media and Cultural Studies took a rather skeptical perspective toward the journalism industry (Wright, 2011). This to a certain extent will influence how junior journalists analyze the news and struggle to craft the 'right' news for the editors. A recent study by Forst (2017) analyzed prevailing journalism education in the United Kingdom. He argued that ethics and the economy would determine the future of journalism education. In the university, there would be a continuing struggle to strike a balance between theoretical knowledge and 
practical skills. Shortage of government funding on education and the journalism industry may lead to issues on the viability of journalism programmes in universities. Nonetheless, Forst (2017) was positive that the journalism industry still preferred university trained graduates as they had always been the intelligent and flexible workforce for the industry.

In the context of Asia, the development of journalism education is also a matter of growing concern. The term Asia here refers to Hong Kong, India, Malaysia, Philippines and Vietnam. One of the seminal works on journalism media was the book edited by Muppidi and Manvi (2008). Inspired by the Asian Media Information and Communication Centre based in Singapore, five countries were selected to provide an overview of journalism education in selected Asian countries. Reporting on the Hong Kong scenario, (Lia, 2008) pointed out that the journalism industry there is one of balancing selfcensorship with press freedom. There were three government funded universities offering journalism programmes, namely the Baptist University of Hong Kong, the Chinese University of Hong Kong and the Chinese University of Hong Kong. Hong Kong Shue Yan College was the only pioneer private university offering a journalism degree. Journalism educators sought internship opportunities for their student journalists by promoting local, regional and global networking links with the media industry based in Hong Kong. Among the challenges faced by the Hong Kong journalism educators were equipping their charges with technological skills, critical thinking and the ability to maneuver through sensitive political news reporting.

Journalism education in India is attracting attention due to the boom in the media industry. There were a few challenges in managing journalism education in India (Muppidi, 2008), i.e., the lack of regulation and oversight on certain important issues. The lack of resources and infrastructure often frustrated journalism educators as they often faced an uphill battle to equip students with the latest skills. Inbreeding was also a challenge as some educators had no real work experience in the journalism industry. There was also the lack of a consistent course curriculum because there was no official regulatory body to monitor the journalism education curriculum. Some curricula were outdated and turned out to be a total mismatch with industry expectations. Finally, there was a lack of industry collaboration with the university. A recent study 
on journalism education in India echoed similar findings to that of Muppidi (2008). It was emphasized by Desai (2017) that the media in India was driven by economics and politics that had resulted in various daunting challenges to journalism education in the country. Due to the nature of the Indian economic and political situation, journalists tended to be more cautious about their safety when writing about sensitive news. Most educators were trained in the West and they had inadvertently allowed their Western oriented understanding of curriculum to dominate their practice. Thus, they had usually neglected the importance of considering local needs. To make matters worse, English newspapers often preferred English literature graduates due to their superior language ability. As a result, journalism students lost out on the jobs that were highly paid and could only be absorbed by vernacular newspapers which paid less.

The colonization by the Spaniards and Americans has coloured the character of journalism education in the Philippines. Free press advocacy is the central aim of journalists in the Philippines. Journalism education has grown from strength to strength in the country, however not without some challenges (Gapasin, Mirandilla, Pascual \& Sanqui, 2008). Professional journalists have been willing to teach at the university in order to share their knowledge. The country has also benefited from institutions that championed the core values of journalism. Steadfast in upholding the principles of professionalism, the journalism industry is poised to develop further as the champion of the freedom of speech. However, there were also issues that needed to be better managed, especially with regard to journalism education in the country. One of the main issues was balancing curriculum content between theory and practice. Journalism educators needed to be involved in researches that would enable them to update their knowledge in the field. Updating the curricula is a must. With mounting political pressure in the country, journalists have to be critical in managing the news, but without compromising their safety.

Vietnam is an emerging economic power house in Asia. Journalism is considered as an elite programme in the country (Nguyen, 2008). Despite being an elite programme, journalism education still faced various challenges. Curriculum has always been theoretically driven. It has to change to have a more practical orientation. This will lead to changes in assessment, that is, from being traditionally 
examination-oriented to a more product based oriented assessment. Students should be taught subject matters in journalism during their first or second year of university studies. Currently, they only take these courses from the third year onwards. Such a curriculum structure will place an unnecessary constraint on the students because they will not be able to apply for internship or work parttime in the industry. News facilities are needed in the universities to enable student journalists to practice their journalism skills while still undergoing their studies. Facilities such as well-equipped libraries should be established in the universities to help students in their studies and journalism educators in their research. In addition, industrial collaboration is welcome as it will enhance the quality of journalism education curriculum development.

China as a thriving economic power house has its own dilemma in journalism education. It serves two masters, namely the government and the public (Han, 2017). Historically, Chinese journalism education has been shaped by the West. The western academic influence was the result of adopting the curriculum from two universities, Missouri and Columbia. American professors from these two universities were hired to teach in Chinese universities. The next phase of development marked a new phenomenon as Chinese journalism education was remodeled after the Sovietmodel of education. Later, it became driven by market forces and currently it is serving two masters. Generally, journalism education in China is doing relatively well; with current acknowledgement of a balanced curriculum, availability of high tech facilities and the strategic manoeuvers of the Communist Party in light of market demands. Nonetheless, it can do better in terms of standardizing the curricula, deciding on a flexible curriculum approach - specialized or general focus, and balancing theory and skills.

It is worth noting that across the above selected cases of journalism education in Asian countries, consistency of curriculum is a prime concern. Perhaps this is due to the fact that most of the journalism schools are influenced by the western framework of education and in turn, have adopted guidelines in curriculum development based the western model. Although one can clearly see the diversity in terms of the social, political and economic challenges that have shaped journalism education in Asia, it is also obvious that the university plays an important role in designing and developing the 
curriculum for journalism education. Taking cognizance of the fact that journalism education has become one of the most influential programmes in Asia, educators in the field are beginning to see the curriculum as a critical area of concern. They have therefore begun to take charge in shaping the curriculum to ensure that the quality of graduates in journalism is second to none.

\section{Perspective from Malaysia}

Journalism education in Malaysia began when higher educational institutions started offering diploma and bachelor degrees in communication and journalism in the 1970s (Luan \& Hoon 2008). Universiti Sains Malaysia (1971) was the first public institution of higher learning in the country to offer a degree programme in journalism. Other universities which followed suit by offering journalism education were Universiti Teknologi MARA (1972), Universiti Kebangsaan Malaysia(1975), University of Malaya (1977) and Universiti Pertanian Malaysia (1979). Among the pressing issues of journalism education in Malaysia are the inadequate number of academic teaching staff, difficulty to send inexperienced lecturers to industry for practical training, lack of critical thinking skills and lack of language competency among the students, especially in the national language and English (Luan \& Hoon, 2008).

Merican (2017) believes that journalism education in Malaysia need to establish its own identity. He proposes sustainable journalism and hopes to reroute journalism education Malaysia to the principle of humanizing news for the nations by incorporating religion, culture and civilization knowledge. Merican (2017) contends that this will enable the journalism curriculum to make sense of its role in the community. At the same time there is the need to link the various branches of knowledge in, for example, technology, policy and other current fields so that the journalism curriculum is holistic in its design and implementation.

A study conducted on journalism education from the student perspective in Malaysia argued that the curriculum is still western based and all about the West (Aripin, Ismail, Yusof \& Ismail, 2015). This phenomenon of borrowing from the West to develop the academic curriculum has happened due to the country's colonialization history and its modernization process (Chan, Lee \& Yang, 2017). 
Today, communication and journalism degrees have expanded and are being offered in most public and private universities in Malaysia. Currently there are nine public and seven private universities offering degrees in journalism (Ismail, Ismail, Yusof \& Aripin, 2015). The increase in the number of Malaysian universities offering journalism degrees is a reflection of the growing market demand for journalism graduates.

Conducting a curriculum review is at the heart of improving a programme of study or course. Many scholars in the field of journalism education have argued that a curriculum review is vital in ensuring the quality of graduates, but the suggestions on elements that have to be included are contextual. Daniels (2012) for example, argues that professors need to teach broad journalism knowledge with the incorporation of hands-on experience in various journalism specializations. On the other hand, Olusegun (2015) argues for the importance of internship in filling the gap between what is taught in the academic setting and practical demands of the current journalism industry. The literature on journalism education has highlighted the importance of the curriculum, especially its role in tackling the following key aspects: skills without knowledge is insufficient (Hugo, 2003); the importance of new media (Ricketson, 2001), innovative thinkers (Cullen et al., 2014), multimedia skills (Wenger \& Owens, 2013), traditional journalism skills are still needed (Nankervis, 2011) and employability demands are incompatible with traditional academic values (Knight \& Yorke, 2003). The literature review on journalism education and curriculum has revealed one glaring theme and that is the growing chasm between employability requirements and academic experience. The imperative is to close the gap between industry demands and academic learning experience, and this means a good curriculum design.

The journalism industry offers unique experiences for graduates. Many scholars hold the view that intervention from industry on curriculum review is vital as journalism is one of the dynamic fields today (Westlund \& Lewis, 2017). This has come about because in a rapidly globalizing world which is witnessing a digital technology revolution, high literacy rate and pressing resource constraints, the discerning audience will start to demand fast and accurate news. Among the strategies to enhance curriculum design is to involve industry players in shaping an aligned curriculum, meeting both the 
demands of academia and industry. Hiring journalists as part-timers, aligning internship programmes to the schedule of the industry and recruiting senior journalists to be part of externals for curriculum review are among other strategies urgently required. The Ministry of Higher Education, Malaysia with the cooperation of the Malaysian Qualifications Agency (MQA) has mandated that every programme offered must be reviewed every one cycle of the programme. As part of the accreditation process, it has become mandatory for universities to appoint a panel comprising members from the relevant industry in the curriculum review process.

Table 1 summarizes the characteristics shared by selected countries in journalism education.

\section{Table 1}

Countries' Experiences in Journalism Education

\begin{tabular}{|c|c|c|c|}
\hline Countries/case & $\begin{array}{l}\text { Curriculum } \\
\text { nature }\end{array}$ & Work skills & Issues of concern \\
\hline Australia & Diverse & $\begin{array}{l}\text { Traditional } \\
\text { journalism work } \\
\text { skills (eg. Writing) }\end{array}$ & $\begin{array}{l}\text { Financial and } \\
\text { resources constraint } \\
\text { and collaboration with } \\
\text { industry }\end{array}$ \\
\hline China & $\begin{array}{l}\text { Theoretical } \\
\text { oriented }\end{array}$ & $\begin{array}{l}\text { Traditional and } \\
\text { advanced journalism } \\
\text { work skills (eg. } \\
\text { Writing and } \\
\text { technological skills ) }\end{array}$ & $\begin{array}{l}\text { Press freedom and } \\
\text { self-censorship and } \\
\text { balanced curriculum }\end{array}$ \\
\hline $\begin{array}{l}\text { Hong Kong, } \\
\text { China }\end{array}$ & $\begin{array}{l}\text { Theoretical } \\
\text { oriented }\end{array}$ & $\begin{array}{l}\text { Traditional } \\
\text { journalism work } \\
\text { skills (eg. Writing) }\end{array}$ & $\begin{array}{l}\text { Press freedom and } \\
\text { self-censorship, } \\
\text { enhance critical } \\
\text { thinking and } \\
\text { technological skills. }\end{array}$ \\
\hline India & $\begin{array}{l}\text { Theoretical } \\
\text { oriented }\end{array}$ & $\begin{array}{l}\text { Traditional } \\
\text { journalism work } \\
\text { skills (eg. Writing) }\end{array}$ & $\begin{array}{l}\text { Financial and } \\
\text { resources constraint, } \\
\text { inbreeding faculty, } \\
\text { lack of industry } \\
\text { collaboration and } \\
\text { press freedom. }\end{array}$ \\
\hline
\end{tabular}




\begin{tabular}{|c|c|c|c|}
\hline Countries/case & $\begin{array}{l}\text { Curriculum } \\
\text { nature }\end{array}$ & Work skills & Issues of concern \\
\hline Malaysia & $\begin{array}{l}\text { Theoretical } \\
\text { oriented }\end{array}$ & $\begin{array}{l}\text { Traditional } \\
\text { journalism work } \\
\text { skills (eg. Writing) }\end{array}$ & $\begin{array}{l}\text { Financial and } \\
\text { resources } \\
\text { constraints, industry } \\
\text { collaboration, soft } \\
\text { skills and advanced } \\
\text { technological skills. }\end{array}$ \\
\hline Philippines & $\begin{array}{l}\text { Theoretical } \\
\text { oriented }\end{array}$ & $\begin{array}{l}\text { Traditional } \\
\text { journalism work } \\
\text { skills (eg. Writing) }\end{array}$ & $\begin{array}{l}\text { Financial and } \\
\text { resources constraints, } \\
\text { balanced curriculum } \\
\text { and press freedom. }\end{array}$ \\
\hline $\begin{array}{l}\text { United } \\
\text { Kingdom }\end{array}$ & $\begin{array}{l}\text { Theoretical } \\
\text { oriented }\end{array}$ & $\begin{array}{l}\text { Traditional } \\
\text { journalism work } \\
\text { skills (eg. Writing) }\end{array}$ & $\begin{array}{l}\text { Financial and } \\
\text { resources constraints, } \\
\text { balanced curriculum } \\
\text { and collaboration with } \\
\text { industry }\end{array}$ \\
\hline $\begin{array}{l}\text { United } \\
\text { States }\end{array}$ & $\begin{array}{l}\text { Industry } \\
\text { oriented }\end{array}$ & $\begin{array}{l}\text { New and traditional } \\
\text { work skills (eg. } \\
\text { Writing and } \\
\text { entreprenuerialship) }\end{array}$ & $\begin{array}{l}\text { Financial and } \\
\text { resources constraints }\end{array}$ \\
\hline Vietnam & $\begin{array}{l}\text { Theoretical } \\
\text { oriented }\end{array}$ & $\begin{array}{l}\text { Traditional } \\
\text { journalism work } \\
\text { skills (eg. Writing) }\end{array}$ & $\begin{array}{l}\text { Financial and } \\
\text { resources constraints, } \\
\text { collaboration with } \\
\text { industry and balanced } \\
\text { curriculum }\end{array}$ \\
\hline
\end{tabular}

\section{Curriculum Models}

The Cyclical Model was chosen as a frame for this study as it offers a flexible perspective in managing the curriculum. In the context of curriculum-instruction relationship, the Cyclical Model requires that instructional designs are derived only after a committee has agreed on the proposed curriculum design (Oliva \& Gordon, 2013). Thus, the process of curriculum development is continuous as feedback from instructional and curriculum committees will have important roles to play in shaping the curriculum. 
Based on the researchers' experiences and guidelines from the MQA, the Taba Model was adapted as the theoretical framework for the study. This selection is in line with other studies in journalism that suggested that it is one of the most suitable models for a journalism curriculum (Pavlik, 2012). Taba's instructional strategies model offers flexibility in curriculum development. It allows curriculum designers to identify specific learning outcomes and later these are aligned to the assessment of the outcomes. These criteria suit the nature of journalism education, which is dynamic and requires innovative teaching in keeping up with the demands of the journalism industry. While the Taba model offers a specific approach on curriculum development, the Cyclical model presents an overview of a curriculum development cycle. Thus, the two models integrate effectively to inform curriculum developers in managing curriculum design.

Taba's grassroots model suggests seven main steps to be followed: 1) Diagnosis of needs, 2) Formulation of objectives, 3) Selection of content, 4) Organization of content, 5) Selection of learning experiences, 6) Organization of learning activities and 7) Evaluation and means of evaluation (Ornstein \& Hunkins, 2014). The approach is inductive and offers constructive feedback to curriculum development. Please refer to Figure 1 for steps in the Taba's Model.

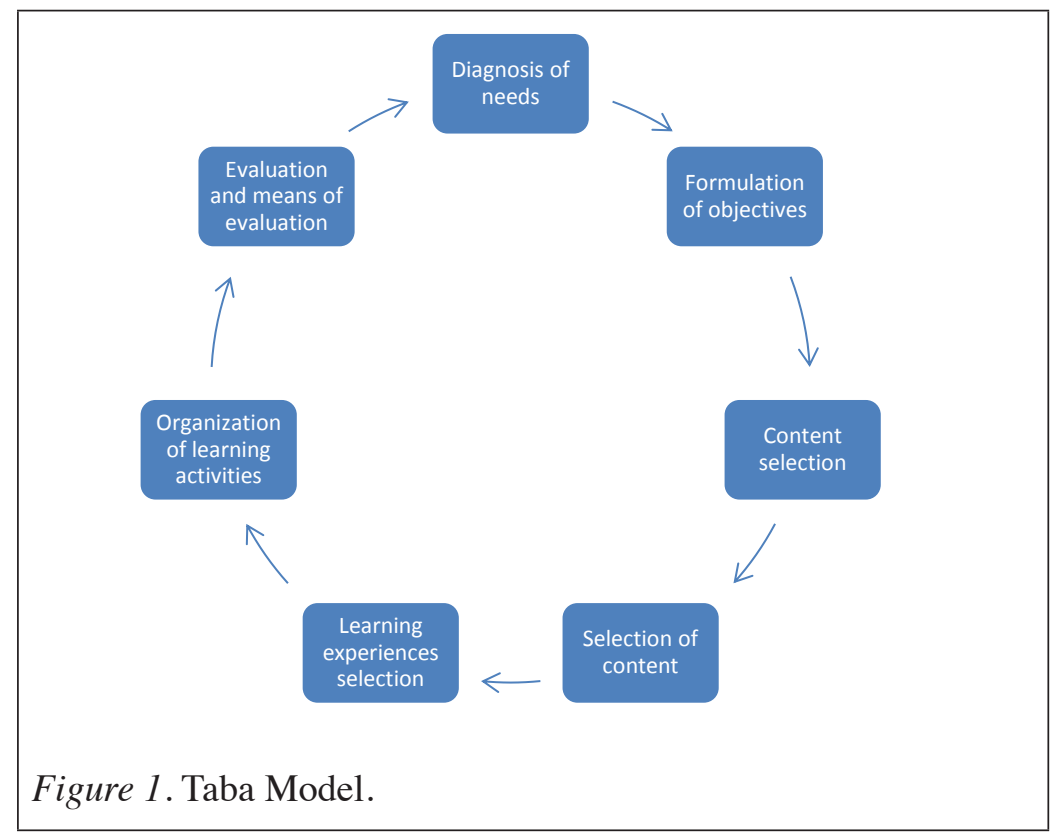


Diagnosis of needs. Based on the needs of the learners, the faculty needs to address the gap between the existing program and the ideal program. During this stage, the team of curriculum developer has to plan a need analysis that involve few stages; 1) Plan and collect data of the industrial viewpoints, policy planner and alumni 2) Compare the findings to the program learning outcomes 3) Identify the gap between the existing and the desired curriculum and 4) Suggest intervention strategies to solve the gaps.

Formulation of objectives. Once the needs analysis is done, the team can formulate the program aim.

Selection of content. From the stated objectives, the team can draw up the curriculum content. Matching the purpose of the program of study and the content is a must. This process will involve many rounds of discussion and debate as it is an intensive analysis of the curriculum content.

Organization of content. Drawing from experiences from the experts in the field, which among other things, may include the scholarship of teaching and learning and teaching, training and research, the team will determine the organization of the content. Learners' socio-demographics, achievements and interests are among other important factors to be considered in organizing the content.

Selection of learning experiences. Once the content is organized, the team has to choose the appropriate pedagogical methods that will help achieve the course learning outcomes.

Organization of learning activities. Next, learning activities need to be organized to meet the course learning outcomes. This process will ensure that the students are able to achieve the course learning outcomes after completing the course.

Evaluation and means of evaluation. Once a course is completed, each of the course learning outcomes will be evaluated to ascertain whether the course purpose has been achieved. It is part of the curriculum development loop that both teachers and students provide constructive feedback in order to help improve the curriculum. 


\section{METHODOLOGY}

The study used the semi-structured interview method. Fifteen industry experts were interviewed. They have served more than 10 years in the media industry and have held various executive positions. The details are as shown in Table 2.

Table 2

Background Details of Experts Interviewed

\begin{tabular}{|c|c|c|c|c|}
\hline Name & Position & Organization & $\begin{array}{c}\text { Work } \\
\text { experience }\end{array}$ & Expert Id \\
\hline Alsagoff & Assistant Editor & $\begin{array}{l}\text { Malaysia Kini } \\
\text { (alternative Malay } \\
\text { newspaper) }\end{array}$ & 26 years & E1 \\
\hline Annuar & Assistant Editor & $\begin{array}{l}\text { Utusan (mainstream } \\
\text { Malay newspaper) }\end{array}$ & 25 years & $\mathrm{E} 2$ \\
\hline Hamid & $\begin{array}{l}\text { Feature Editor } \\
\text { and Op Ed }\end{array}$ & $\begin{array}{l}\text { Berita Harian } \\
\text { (mainstream Malay } \\
\text { newspaper) }\end{array}$ & 26 years & E3 \\
\hline Nazim & Assistant Editor & $\begin{array}{l}\text { NST (mainstream } \\
\text { English newspaper) }\end{array}$ & 34 years & $\mathrm{E} 4$ \\
\hline Jazli & $\begin{array}{l}\text { Group Editor } \\
\text { (Retired) }\end{array}$ & $\begin{array}{l}\text { Media Prima (news } \\
\text { based industry). }\end{array}$ & 42 years & E5 \\
\hline Husin & Editor & $\begin{array}{l}\text { Kosmo (Malay } \\
\text { tabloid) }\end{array}$ & 26 years & E6 \\
\hline Malik & Editor & $\begin{array}{l}\text { Berita Harian } \\
\text { (mainstream Malay } \\
\text { newspaper) }\end{array}$ & 24 years & E7 \\
\hline Izam & Senior journalist & $\begin{array}{l}\text { Mstar (Malay section } \\
\text { of mainstream } \\
\text { English newspaper) }\end{array}$ & 10 years & E8 \\
\hline Mohd & $\begin{array}{l}\text { Group Editor } \\
\text { (Retired) }\end{array}$ & $\begin{array}{l}\text { Mainstream news } \\
\text { organization }\end{array}$ & 42 years & E9 \\
\hline Nor & Senior journalist & $\begin{array}{l}\text { Mstar (Malay section } \\
\text { of mainstream } \\
\text { English newspaper) }\end{array}$ & 23 years & E10 \\
\hline
\end{tabular}




\begin{tabular}{lllcc}
\hline Name & Position & \multicolumn{1}{c}{ Organization } & $\begin{array}{c}\text { Work } \\
\text { experience }\end{array}$ & Expert Id \\
\hline Sarah & Senior journalist & $\begin{array}{l}\text { Berita Harian } \\
\text { (Malay mainstream } \\
\text { newspaper) }\end{array}$ & 24 years & E11 \\
Jihan & CEO (retired) & $\begin{array}{l}\text { Mainstream news } \\
\text { organization }\end{array}$ & E12 \\
Tam & Associate Editor & $\begin{array}{l}\text { Berita Harian } \\
\text { (mainstream Malay } \\
\text { newspaper) }\end{array}$ & E13 \\
Zul & Editor & $\begin{array}{l}\text { Utusan (mainstream } \\
\text { Malay newspaper) }\end{array}$ & 25 years \\
Jamal & News Editor & $\begin{array}{l}\text { Berita Harian } \\
\text { (mainstream Malay } \\
\text { newspaper) }\end{array}$ & E15 \\
& & 26 years & \\
\hline
\end{tabular}

The interview protocol was developed based on the literature review carried out for this study and the guidelines on the review of the Communication and Media Studies curriculum. The researchers examined each of the university courses that offered journalism programs in Malaysia. The team decided to conduct the interview using play cards that denoted main subjects that were offered in journalism schools or programs in Malaysia. The subjects fell under the following broad categories: 1) general knowledge (economics and politics),2) specialized journalism subjects (news writing, basic broadcasting), 3) communication subjects (public relations and marketing).

Thus, in the interview process the interviewees were first showed cards that had listed subjects that were being offered in the institutions of higher learning concerned and they were then asked on their views on the subject matter. We also asked them about their overall perspective on curriculum design on journalism education as envisaged by the industry.

The interviews were conducted at the offices and homes of the interviewees. Each interview took about one to two hours. The interview data was manually transcribed by the two research assistants engaged for the study. After that, the researchers read through the transcripts and analyzed the data. Initial themes were first 
identified. Then a second reading was done to identify main themes and subthemes. Once the team was satisfied with the elaborations of the themes and sub-themes based on the interview guidelines and literature reviews, the themes were finalized.

\section{RESULTS}

Based on the thematic analysis (Braun \& Clarke, 2006) carried out in this study, the findings revealed the following four main themes: 1) Strong general knowledge requirement. 2) The right skills matter 3) Interest in the field - ability to adapt and learn and 4) Specialized knowledge.

\section{Strong General Knowledge Requirement}

It is interesting to note that general knowledge is fundamental in order to nurture good journalism students. This theme has been emphasized strongly by the experts. The reason for this is that in order to develop a good news write-up, a journalist has to understand the core of the issue and this can only be achieved when the journalist has strong general knowledge. The following are some excerpts from the interviews with the experts:

"It is a requirement for a journalist to have strong general knowledge. It would make their life easier to understand the issue that they have to cover. It gives them more sense on how to see things from various angles" (E2)

"It is almost impossible to be a good journalist without good general knowledge. Keep on learning on various subject matters. Journalism is about knowledge and experience. And general knowledge is essential in developing a good news" (E5)

"What makes us (journalist) unique is the ability to learn fast. Of course among the main requirement is the general knowledge. If you go to press conference without knowing the Minister name and interest, then you are in deep trouble to prepare the news" (E11) 


\section{The Right Skills Matter}

There is always a debate between academia and industry on the right skills that have to be acquired by the students of journalism. As each party has its own strengths and constraints, getting input from the experts on what really matters in the industry is important, as can be seen from the views expressed below by the experts interviewed:

"We need students to have basic skills that they could learn from their universities. They will learn more when they work with us. But without basic skills, they are putting themselves in trouble" (E14)

"Journalism nowadays is a fast changing field. What they learn in the university is important but they need to be openminded and learn new skills fast here. We acknowledge that some universities of have good training facilities while some do not" (E13)

"Technology skills are important nowadays. But it could not work if you have no basic in journalism skills such as writing, researching, producing videos and interviewing" (E3)

\section{Interest in the Field - Ability to Adapt and Learn}

Journalism is a flexible field yet one must be very passionate to enter the field. It is flexible in the sense that it opens up opportunities for graduates from various backgrounds to enter the profession. However, one has to have great passion for the calling to stay in the field. It is common practice among hiring committees in media industries to hire journalists from various study backgrounds such as those majoring in history and language. However, with the present development in journalism education, journalism graduates are now preferred compared to other graduates due to their specialized journalism skills and knowledge. However, to survive in the industry, one has to be interested to adapt and learn new skills most of the time. As stated by the experts:

"Journalists are special species. We are here because of our passion. If juniors want to stay longer in the industry, they need to find their interest or else it is a punishing career" (E7) 
"You can be a graduate in social science but if you have the ability to learn, journalism is career for you" (E4)

"It is common for journalist to have gastric issue due to busy work schedule. It is like a badge that we wear during our junior years" (E11)

"Present demand is the ability to be multi-tasking and electronically savvy. It is a transformation from what we had experiences in the past with less gadget in the industry. Thus, a journalist needs to keep up with the new technology based skills and produce timely news with accuracy. It is hard and that why we need passionate people to be here" (E13)

"The ability to adapt to the new environment is a skill to be mastered by the future journalists. With present demands of fast feedback and online news, journalists are facing new challenges in their careers. Thus, the ability to adapt and learn is vital to survive as a journalist" (E8)

\section{Specialized Knowledge}

In the field of journalism there are several genres which require experts who have undergone intensive training in specialized subject matters. Among the genres are crime, economy, science, law and business. These areas of specialization demand that the journalist have a deep knowledge of the area concerned. Normally, the management would prefer to employ graduates from specific disciplines, for example in law and business these graduates are interested in becoming journalists in those genres. The views expressed below by the experts in the industry serve to illustrate this point:

"It is not easy to train journalists to acquire specialized knowledge. It is much easier to employ those who have specialized degrees and train them to become journalists" (E5)

"The senior editors acknowledge that they require experts in certain fields. Of course, the challenge is to develop the flair in writing and the ability to acquire journalist skills" (E9) 
"There are areas where journalism students normally can enter if they have enough knowledge especially when it requires specialized knowledge. Due to this fact, we would rather recommend to employ graduates with specialized degree for the job" (E12)

The challenge in this regard is whether the employers have the ability to sustain the interest of their employees in the workplace. The trend nowadays for most media industries is to offer training in writing for the non-journalism graduates so that they can keep up with the required genre of writing peculiar to the particular media industry they are in. It is not an easy task, but as most of the job applicants are eager to work in the particular media industry, they tend to adapt and learn fast the techniques in writing the specific genre.

\section{DISCUSSION}

The findings clearly show that it can be quite a challenge for curriculum designers to adapt to the demands of the industry. However, with the Taba curriculum design model, it is possible to have a hybrid journalism education curriculum with academic emphasis. Opening universities to industry networking offers vast opportunities to engage in collaboration and to work towards developing a better journalism curriculum. Input from the industry, especially tapping its strengths on specialized knowledge, skills and passion to be a journalist, are elements which are important in the Taba curriculum model.

Having recourse to the Cyclical Model and adapting the curriculum model by Taba, the diagnosis of needs in the study led to the use of themes in the discussion of the findings. The curriculum designers can formulate appropriate learning objectives based on the specified needs and depending on their suitability to the current curriculum structure.

The findings are consistent with the emphasis of journalism scholars, which is that knowledge is vital in order to become a good journalist (Merican, 2017). Grounded in the local context but with access to global information, journalists need to develop a strong general knowledge base when covering news. Even though general knowledge subject matter is not always covered in a journalism 
curriculum, it is an initiative on the part of journalism schools to ensure that student journalists are exposed to general knowledge as it will help them in the working environment.

It is imperative to provide both general and specialized knowledge in the journalism curriculum today. Both types of knowledge can be embedded in either the minor or electives courses. The content can come from a journalism school or from other schools offering other subjects in the social sciences. Perhaps the academics in charge of journalism studies can collaborate with the coordinator of the core subject matters, i.e., dealing with general or specialized knowledge so as to align all the required programme learning outcomes from the different subjects in the course structure.

Selection of learning experiences can be a hybrid of academic and industrial requirements. The course learning outcomes will have to reflect the nurturing of the right skills required of journalism students. With the present emphasis on student centered learning strategies, instructional design will have to look into the use of the appropriate pedagogical styles such as service learning and problem based learning for journalism students. As most lecturers in Malaysia have been exposed to student centered learning strategies, this will augur well for the change in pedagogical styles.

Evaluation and means of evaluation must also be revamped to be less exam-oriented. This could be done for example, by increasing the amount and types of formative assessment that will facilitate the development of student knowledge and skills in a much more meaningful manner. The importance of using feedback from stakeholders such as industry or students in aligning the curriculum to the learning outcomes and learning instruction is critical. This was amply demonstrated by Webb and Moallem (2016) in their study on student feedback to inform curriculum designers on instructional design in online problem based learning.

An additional matter that should be considered by the curriculum developer is to include a good internship programme in the structure of the course. Internship programmes can make or break students. In Malaysia, journalism schools make such a programme compulsory. However, the period of internship varies from four to six months. Ultimately, the choice of internship is crucial. Sending students to the industry is a challenge as it involves at least three main parties, 
the intern, the company or institution and the university. Moreover, students or interns are always concerned about financial matters, especially if they are placed in urban areas with a low allowance. Some companies or institutions do offer allowances for travelling and the appointment as an intern.

Internship programmes should enhance the critical thinking skills of the students as they provide a window of opportunity to experience a glimpse of the working world. The media industry enjoys an extensive local and global network of media players; it therefore makes good sense for every journalism institution and programme to establish a good relationship with the media. Scholars have often lamented that there is the need to have experienced journalists teaching in journalism schools (Foote, 2017; Muppidi \& Manvi, 2008). Journalists are usually members of a tight network of professionals and they trust their associates when it comes to recommendations for internship and so forth. At the same time, journalism schools are also in a dilemma as most senior journalists do not have paper qualifications that will enable them to teach in Malaysia. Nonetheless, some universities that are situated in urban areas enjoy the advantage of inviting senior journalists to give talks and share their experiences with the students. This will help to build the passion and interest of the students before they enter the industry for their internship.

The objective is to have all the necessary and sufficient criteria as the outcomes of the program learning outcomes, such that the curriculum can be tailored to the needs of the industry and at the same time be fulfilling the academic requirements. This is because the curriculum is not about creating a super journalist, but to develop a humanistic journalist who cares about the essential values of the profession. It is about nurturing student journalists who will be able to contribute to the industry as well as serve the wider community.

\section{CONCLUSION}

Curriculum design is vital in offering meaningful learning to students. Feedback from experts in the industry is also important as it keeps the curriculum up to date and relevant to the field. Educationists with extensive experience in the field are without doubt, in a better 
position to understand the need to strike a balance in the teaching of skills and knowledge to journalism graduates. Future research should investigate further the impact of curriculum development in journalism education on journalism graduates and the industry.

\section{ACKNOWLEDGEMENT}

The authors wish to thank the Ministry of Higher Education Malaysia in funding this study under Fundamental Research Grant Scheme (FRGS), s/o code 13264, and the Research and Innovation Management Centre, Universiti Utara Malaysia, Kedah for the administration of this study.

\section{REFERENCES}

Anderson, C.W. (2017). Venture labor, media work, and the communicative construction of economic value: Agendas for the field and critical commentary. International Journal of Communication, Forum, 2033-2036.

Aripin, N., Ismail, A., Yusof, N., \& Ismail, R. (2015). Shaping the journalism education studies in Malaysia: The effects from the study of ethnicity. Malaysian Journal of Communication, 31(2), 323-340.

Braun, V. \& Clarke, V. (2006) Using thematic analysis in psychology. Qualitative Research in Psychology, 3, 77-101.

Callaghan, R. \& McManus, J. (2010). Building the perfect graduate: What news employers want in new hires. Asia Pacific Media Educator, 20(1), 9-21. http://ro.uow.edu.au/apme/voll/ iss 20/2/

Chan, S-J., Lee, M.N.N.., \& Yang, R. (2017). The hybrid university in East Asia: searching for the new paradigm. Studies in Higher Education, 10 (1), 1803-1808.

Cullen, T., Tanner, S. J.., O’Donnell, M. and Green, K. (2014). Industry needs and tertiary journalism education: Views from news editors', Transformative, innovative and engaging. Proceedings of the 23rd Annual Teaching Learning Forum, University of Western Australia, Australia, pp. 1-11.

Daniels, S. (2012, November 06). Young journalists today: Journalism students' perceptions of the ever-evolving industry. Retrieved 
from https://digital.library.unt.edu/ark:/67531/metadc115063/ $\mathrm{m} 1 / 1 /$

Desai, M. K. (2017). Journalism education in India. In R. S. Goodman \& E.Steyn (Eds.),Global journalism education in the 21 ${ }^{\text {st }}$ century: Challenges \& innovations (pp. 113-136). University of Texas at Austin: Knight Centre for Journalism in Americas.

English, P., Fynes-Clinton, J., \& Barnes, R. (2016). Roles, routines, and responsibilities: The 3Rs of educating journalists for local government reporting. Australian Journalism Review, 38(2), 73-84.

Foote, J. (2017). Journalism education's first century: Markers of progress. In R.S. Goodman, \& E. Steyn (Eds.), Global journalism education in the $21^{\text {st }}$ century: Challenges \& innovations (pp. 429-448). University of Texas at Austin: Knight Centre for Journalism in Americas.

Frost, C. (2017). Squeezed between the newsroom and classroom. In R. S.Goodman \& E. Steyn (Eds.), Global journalism education in the $21^{\text {st }}$ century: Challenges \& innovations (pp. 199-218). University of Texas at Austin: Knight Centre for Journalism in Americas.

Gapasin, A.R., Mirandilla, K.M., Pascual, M.R. S.S., \& Sanqui, D.C. V. (2008). Journalism education in the Phillipines. In Muppidi, S. R., \& Manvi, P.(Eds), Media Asia: Journalism education in Asia (pp. 101- 109). Singapore: AMIC.

Gilmor, D. (2016). Towards a new model for journalism education. Journalism Practice, 7, 815-819.

Han, G. (2017). Journalism education in China: Serving the two masters.In R.S.Goodman \& E. Steyn(Eds.), Globaljournalism education in the $21^{\text {st }}$ century: Challenges \& innovations, 6590. University of Texas at Austin: Knight Centre for Journalism in Americas.

Hugo, d. B. (2003). Skills are not enough: The case for journalism as an academic discipline. Journalism, 4 (1), 95-112.

Ismail, A., Ismail, R., Yusof, N., \& Aripin, N. (2015). Journalism education in Malaysia: Dancing with UNESCO's model curricula. International Journal of Science Commerce and Humanities, 3 (3), 1-10.

Knight, P. \& Yorke, M. (2003). Assessment, learning and employability. Maidenhead: Society for Research into Higher Education and Open University. 
Lia, W. (2008). Journalism education in Hong Kong. In Muppidi, S. R., \& Manvi, P. (Eds.), Media Asia: Journalism education in Asia (pp. 60- 66). Singapore: AMIC.

Luan, N. W., \& Hoon, L.L. (2008). Journalism education in Malaysia. In Muppidi,S. R., \& Manvi ,P. (Eds.), Media Asia: Journalism education in Asia (pp. 84- 100). Singapore: AMIC.

Muppidi, S.R. (2008). Journalism education in India. In Muppidi, S. R., \& Manvi, P. (Eds), Media Asia: Journalism Education in Asia, (pp. 67-83).Singapore: AMIC.

Muppidi, S. R., \& Manvi , P. (Eds). (2008) Media Asia: Journalism education in Asia, 101- 109, Singapore: AMIC.

Merican,A. M. (2017). Sustainability journalism as discourse among civilizations: Concept and dialogue. Katha, [S.1.], v. 10, n. 1, p. 26 - 40, aug. 2017. ISSN 1823-2159. Retrieved from http://ajba.um.edu.my/index.php/KATHA/article/view/5814

Nankervis, K. (2011). Pushing the right buttons? Training television journalists in the digital age. Australian Journalism Review, $33(1), 119-130$.

Nguyen, A. (2008). Journalism education in Vietnam. In Muppidi, S. R., \& Manvi, P.(Eds). (2008), Media Asia: Journalism education in Asia, 101-130,Singapore: AMIC.

Oliva, P. F., \& Gordon, W. II. (2013). Developing the curriculum. Boston: Pearson.

Olusegun, O. (2015). Journalism trainers and newspapers editors agree on internship as a weak link in journalism training in Nigeria. International Journal of Humanities and Social Science, 5 (4), 104-111.

Pavlik, J. V. (2012). Reforming Iraqi journalism and mass communication higher education: Adapting the UNESCO model curricula for journalism education to Iraqi higher education. Journalism \& Mass Communication Educator, 67(3), 268-285.

Ricketson, M. (2001). All things to everyone: Expectations of tertiary journalism education. Asia Pacific Media Educator, 10, 94-99.

Ryfe, D., \& Messing, D. (2013). Blueprint for change: From the teaching hospital to the entrepreneurial model of journalism education. Retrieved from https://www. academia.edu/3412374/Blueprint_for_Change_From_the_ Teaching_Hospital_to_the_Entrepreneurial_Model_of_ Journalism_Education 
Tanner, S. J., O’ Donnell, M., Cullen. T., \& Green, K. (2013). Graduate qualities and journalism renewal: Balancing tertiary expectations and industry needs in a changing environment. University of Wollongong, Research Online. Retrieved from: http://docplayer.net/18539970-Graduatequalities- and-journalism-curriculum- renewal-balancingtertiary-expectations-and-industry-needs-in-a-changingenvironment.html\#show_full_text

Temple, M. (2009). The future of journalism education in the United Kingdom: a personal view from the academy. MediAnali, 3 (5), 241-258.

Webb, A., \& Moallem, M. (2016). Feedback and feed-forward for promoting problem-based learning in online learning environments. Malaysian Journal of Learning and Instruction, 13 (2), 1-41.

Wenger, D., \& Owens, L. C. (2013). An examination of job skills required by top U.S. broadcast news companies and potential impact on journalism curricula. Electronic News, 7 (1), 2235.

Westlund, O., \& Lewis, S. C. (2017). How understanding the interplay of actors, actants, and audiences can improve journalism education. In R. S. Goodman \& E.Steyn (Eds.), Global journalism education in the $21^{\text {st }}$ century: Challenges \& innovations (pp. 409-428). University of Texas at Austin: Knight Centre for Journalism in Americas.

Wright, K. (2010). Reality without scare quotes: Developing the case for critical realism in journalism research. Journalism Studies, 12 (2), 156-171. 